\title{
Respons Dinamik Pelat Beton Akibat Beban Kendaraan yang Bergerak dengan Kecepatan Konstan
}

\author{
"Yenny Untari Liucius1, Sofia W. Alisjahbana ${ }^{2}$ \\ ${ }^{1}$ Jurusan Teknik Sipil, Universitas Tarumanagara, Jakarta \\ ${ }^{2}$ Universitas Bakrie, Jakarta \\ *) untariyenny@gmail.com
}

Received: 24 Agustus 2018 Revised: 24 Juni 2019 Accepted: 26 Juni 2019

\begin{abstract}
This analysis studies about the dynamic response of isotropic slab with the semi rigid type of edge conditions which is solved by the Modified Bolotin Method. The dynamic response mostly depends on the characteristics of the slab and the velocity of the transverse load acting on the slab. This analysis uses $10 \mathrm{~km} / \mathrm{h}, 20 \mathrm{~km} / \mathrm{h}$, and $30 \mathrm{~km} / \mathrm{h}$ as the velocity of the transverse load, and $110 \mathrm{~km} / \mathrm{h}$ as the comparing velocity. Results show that maximum dynamic responses for each velocity does not always occur on the center of the slab, so the characteristics of the slab may be vary. The dynamic response is closest to maximum when the velocity of the load is $110 \mathrm{~km} / \mathrm{h}$ because it is closer to the critical velocity of the system which is $112 \mathrm{~km} / \mathrm{h}$. This analysis assumed the slab is used for the bus' parking ramp. Thus with the $10 \mathrm{~km} / \mathrm{h}$ until $30 \mathrm{~km} / \mathrm{h}$ velocity assumption for parking ramp is still quite safe because the velocity is far below the critical velocity of the system. Also the dynamic response of the system is far lower than the maximum response of slab.
\end{abstract}

Keywords: Semi rigid, isotropic, modified bolotin method, critical velocity.

\begin{abstract}
Abstrak
Analisis ini mengkaji tentang respons dinamik pelat isotropik dengan perletakan semi rigid yang diselesaikan dengan Modified Bolotin Method.Respons dinamik pelat sangat dipengaruhi oleh karakteristik pelat dan kecepatan beban transversal yang bekerja pada pelat tersebut. Besarnya kecepatan beban yang dianalisis pada penelitian ini adalah sebesar $10 \mathrm{~km} / \mathrm{jam}, 20 \mathrm{~km} / \mathrm{jam}$, dan $30 \mathrm{~km} / \mathrm{jam}$, dan $110 \mathrm{~km} / \mathrm{jam}$ sebagai kecepatan pembanding. Hasil analisis menunjukkan bahwa besarnya respons dinamik maksimum tidak selalu terjadi pada pusat pelat sehingga setiap kecepatan beban memiliki karakteristik sifat pelat yang berbeda-beda. Respons dinamik pelat mendekati maksimum pada saat kecepatan beban sebesar $110 \mathrm{~km} / \mathrm{jam}$ karena mendekati kecepatan kritis sistem yaitu sebesar $112 \mathrm{~km} / \mathrm{jam}$. Analisis dilakukan dengan asumsi model pelat untuk pelat parkir bus pariwisata. Dengan demikian dengan asumsi kecepatan sistem sebesar10 km/jam sampai $30 \mathrm{~km} / \mathrm{jam}$ untuk pelat parkir masih cukup aman karena jauh dari kondisi kecepatan kritis sistem. Respons dinamik sistem juga terbukti masih jauh lebih rendah dari respons maksimum pelat.
\end{abstract}

Kata kunci: Semi rigid, isotropic, modified bolotin method, kecepatan kritis.

\section{Pendahuluan}

Pelat merupakan struktur bidang yang lurus dan merupakan komponen struktural dua dimensi serta permukaan bidangnya tidak melengkung (datar) dengan ketebalan yang jauh lebih kecil dari ukuran dimensi lainnya yaitu panjang dan lebarnya (Szilard, 1974).Pelat merupakan salah satu komponen yang penting dalam suatu konstruksi. Pelat berfungsi sebagai tempat berpijak dan berperan untuk menambah kekakuan horizontal sehingga pelat juga berhubungan langsung dengan faktor kenyamanan dan kekuatan. Beban yang terjadi pada pelat baik statik maupun dinamik biasanya bekerja tegak lurus (transversal) pada permukaan pelat.

Berkaitan dengan unsur kenyamanan dan kekuatan tersebut, maka perlu dipelajari lebih lanjut mengenai respons dinamik pelat akibat beban Respons dinamik yang dihasilkan dipengaruhi oleh banyak faktor, diantaranya adalah ukuran pelat, 
asumsi perletakan yang digunakan pada sisi-sisi pelat, dan kecepatan beban.

Terdapat beberapa jenis penyelesaian untuk permasalahan respons dinamik dari pelat lantai. Namun pada umumnya, metode-metode yang telah ada sebelumnya seperti finite difference, finite element, Rayleigh-Ritz, dan Deret Fourier memberikan hasil yang kurang akurat pada mode yang lebih tinggi (King \& Lin, 1973). Oleh karena itu, salah satu metode yang dapat digunakan untuk penyelesaian pelat pada mode yang lebih tinggi adalah dengan Bolotin Method yang kemudian dikembangkan menjadi Modified Bolotin Method (MBM). Metode ini digunakan untuk menyelesaikan masalah pelat dan cangkang (shell) secara numerik dengan menggunakan fungsi trigonometri (Pevzner et al., 2000). MBM akan memberikan hasil yang lebih akurat untuk ragam getar yang lebih tinggi dengan kondisi perletakan yang beragam.

Pada penelitian ini akan dibahas penyelesaian respons dinamik pelat isotropik yang dibebani dengan beban transversal berjalan seperti yang ditunjukkan pada Gambar 1 berikut.

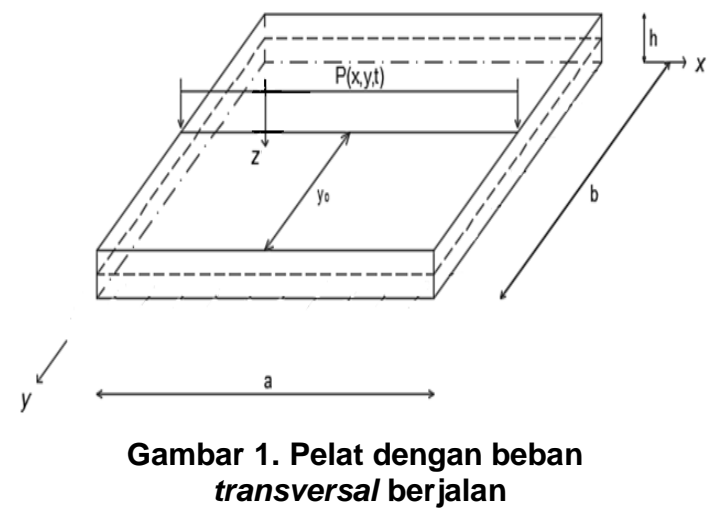

Material yang digunakan dalam struktur pelat dalam penelitian ini adalah beton sehingga pelat memiliki sifat isotropik, yaitu memiliki kekakuan yang sama di segala arahnya. Asumsi yang digunakan untuk perletakan pelat pada keempat sisinya adalah semi rigid sehingga akan digunakan Modified Bolotin Method untuk penyelesaian respons dinamik pelat.

Analisis akan dilakukan sesuai dengan teori Bernoulli yaitu penampang tetap rata sebelum dan setelah dibebani sehingga dalam perhitungan deformasi geser diabaikan karena nilainya sangat kecil. Analisis juga dilakukan pada batasan dimana hokum Hooke masih berlaku. Pada struktur bersifat linear yang mengikuti hokum Hooke, prinsip superposisi dapat diterapkan (Timoshenko \& Goodier, 1951). Defleksi maksimum yang dianalisis pada pelat tidak melebihi $1 / 10$ dari ketebalan pelat, sesuai dengan teori lendutan kecil (small deflection theory).

Penyelesaian permasalahan getaran bebas akan dilakukan secara non-dimensional sedangkan penyelesaian untuk getaran paksa akan dilakukan secara dimensional dengan mengubah frekuensi alami non-dimensional menjadi frekuensi alami dimensional.

Persamaan gerak pelat lantai bangunan dapat diperoleh dengan menggunakan hukum Newton II yang dapat dinyatakan sebagai berikut:

$\sum \mathrm{F}=\mathrm{m} \cdot \mathrm{a}$

Berdasarkan Hukum Newton II, persamaan gerak sistem dengan menggunakan keseimbangan gaya dan reaksi yang bekerja pada pelat dapat dinyatakan sebagai berikut:

$\mathrm{F}_{\mathrm{E}}+\mathrm{F}_{\mathrm{i}}+\mathrm{F}_{\mathrm{D}}=\mathrm{p}(\mathrm{x}, \mathrm{y}, \mathrm{t})$

Dalam persamaan (2) di atas:

$\mathrm{F}_{\mathrm{E}}=$ Gaya dalam lateral elastik akibat gaya vertikal.

$F_{E}=D\left(\frac{\partial^{4} w}{\partial x^{4}}+\frac{\partial^{4} w}{\partial y^{4}}+2 \frac{\partial^{4} w}{\partial x^{2} \partial y^{2}}\right)$

$\mathrm{F}_{\mathrm{i}}=$ Gaya inersia lateral yang merupakan gaya dalam lateral pelat akibat adanya percepatan pada gerak lendutan pelat dan arahnya selalu berlawanan dengan arah gerak lendutan pelat.

$F_{i}=\rho h \frac{\partial^{2} w}{\partial t^{2}}$

$\mathrm{F}_{\mathrm{D}}=$ Gaya redaman viskous ekivalen yang merupakan gayaredaman dari keseluruhan sistem pelat dan arahnya selalu berlawanan dengan arah lendutan transversal pelat dan bersifat proporsional terhadap kecepatan sistem (Paz, 1985). Menurut Are et al (2013) dan Gbadeyan et al (2008), redaman memiliki peranan yang penting pada getaran suatu struktur solid sehingga akan mempengaruhi profil defleksi dari struktur tersebut. Besarnya pengaruh tersebut dipengaruhi dari besarnya koefisien redaman yang digunakan (Idowu et al., 2013). Bila struktur berosilasi tanpa adanya redaman, maka struktur tersebut akan terus mengalami gerak harmonis untuk waktu yang tidak terbatas (Chopra, 2012).

$$
F_{D}=\gamma \cdot h \frac{\partial w}{\partial t}
$$

$\mathrm{p}(\mathrm{x}, \mathrm{y}, \mathrm{t})$ adalah gaya transversal luar yang bekerja pada pelat. Menurut Gibigaye et al (2016) dengan menggunakan persamaan (3), (4) dan (5), persamaan gerak pelat secara umum dapat dinyatakan sebagai berikut (dimensional): 
$D\left(\frac{\partial^{4} w}{\partial x^{4}}+2 \frac{\partial^{4} w}{\partial x^{2} \partial y^{2}}+\frac{\partial^{4} w}{\partial y^{4}}\right)+\rho \cdot h\left(\frac{\partial^{2} w}{\partial t^{2}}\right)+\gamma \cdot h \frac{\partial w}{\partial t}=p_{z}(x, y, t)$

Dalam persamaan (6) di atas: D merupakan kekakuan lentur pelat yang didapat dari $\frac{E \cdot h^{3}}{12\left(1-v^{2}\right)}$,

$\rho$ merupakan massa jenis. h merupakan Tebal pelat. $\Gamma$ merupakan koefisien rasio redaman. w $(\mathrm{x}, \mathrm{y}, \mathrm{t})$ merupakan fungsi lendutan yang tergantung pada fungsi posisi dan fungsi waktu. $\mathrm{p}(\mathrm{x}, \mathrm{y}, \mathrm{t})$ merupakan fungsi beban transversal yang bergantung pada fungsi posisi dan waktu.

Syarat batas yang berlaku adalah sebagai berikut: Pada $\mathrm{x}=0$ dan $\mathrm{x}=\mathrm{a}: \mathrm{n}(7)$

$$
\begin{aligned}
& W(x, y, t)=0 \text { dan }-D\left(\frac{\partial^{2} W}{\partial x^{2}}+v \frac{\partial^{2} W}{\partial y^{2}}\right)=k_{1} \frac{\partial W}{\partial x} \\
& \text { Pada } \mathrm{y}=0 \text { dan } \mathrm{y}=\mathrm{b}:(9) \\
& W(x, y, t)=\mathrm{Odan}-D\left(\frac{\partial^{2} W}{\partial x^{2}}+v \frac{\partial^{2} W}{\partial y^{2}}\right)=k_{2} \frac{\partial W}{\partial y}
\end{aligned}
$$

Kemudian untuk penyelesaian getaran bebas, dengan $\mathrm{a}=$ lebar pelat, $\mathrm{b}=$ panjang pelat, $\xi=\mathrm{x} / \mathrm{a}$, $\eta=\mathrm{y} / \mathrm{b}$, dan $\mathrm{s}=\mathrm{a} / \mathrm{b}$, maka persamaan gerak pelat yang digunakan adalah persamaan non-dimensional sebagai berikut:

$\left(\frac{\partial^{4} w}{\partial \xi^{4}}\right)+2 \cdot s^{2}\left(\frac{\partial^{4} w}{\partial \xi^{2} \partial \eta^{2}}\right)+s^{4}\left(\frac{\partial^{4} w}{\partial \eta^{4}}\right)+\frac{a^{4} \rho h}{D} \frac{\partial^{2} w}{\partial t^{2}}=0$

Alisjahbana \& Wangsadinata (2006) juga menggunakan MBM pada penelitiannya mengenai respons dinamik pelat persegi panjang orthotropik yang berada di atas pondasi Pasternak dan dibebani oleh beban transversal dinamik yang bergerak dengan kecepatan konstan. Pelat tersebut memiliki perletakan yang tidak simetris pada seluruh sisinya sehingga solusi dari persamaan diferensial homogen sistem tersebut diselesaikan dengan MBM.

Untuk masalah pelat dengan perletakan tidak simetris pada keempat sisinya, wave number dinyatakan sebgai $\mathrm{p} \pi / \mathrm{a}$ dan $\mathrm{q} \pi / \mathrm{b}$ dengan $\mathrm{p}$ dan $\mathrm{q}$ adalah bilangan riil yang perlu diselesaikan dengan dua buah persamaan auxiliary tipe Levy pertama dan kedua. Metode inilah yang dinamakan dengan Modified Bolotin Method (Pevzner et al., 2000). Penyelesaian ini dinilai memberikan hasil frekuensi natural dan ragam getar yang paling akurat dengan cara penyelesaian persamaan transcendental yang paling mudah (Elishakoff, 1974).

Penelitian mengenai pelat yang duduk di atas pondasi elastis dan dibebani oleh beban dinamik dilakukan oleh Alisjahbana \& Wangsadinata (2008) serta Beskou \& Thedorakopoulos (2011). Alisjahbana \& Wangsadinata (2008) melakukan penelitian tentang pelat orthotropik teredam yang duduk di atas pondasi Pasternak dengan beban dinamik yang bergerak dengan kecepatan konstan. Beban dinamik yang diberikan bergerak terhadap sumbu $\mathrm{x}$ dan sumbu y pelat dengan kecepatan konstan. Penelitian ini memberikan hasil bahwa MBM dan metode integral Duhamel dapat dilakukan untuk penyelesaian masalah perilaku dinamik dari pelat orthotropik yang teredam dan duduk di atas pondasi Pasternak yang dibebani oleh beban dinamik dengan kecepatan konstan. Selain itu, jenis dari kondisi beban juga mempengaruhi respons dinamik dari pelat.

Alisjahbana \& Wangsadinata (2012) juga mempelajari tentang analisis dinamik terhadap perkerasan jalan yang dibebani beban kendaraan dengan kecepatan tidak konstan. Penelitian ini menggunakan MBM untuk penyelesaian frekuensi alami dan mode shape. Pelat dimodelkan duduk di atas pondasi Pasternak. Keempat sisinya diasumsikan menggunakan dowel dan tie bar sebagai perletakan dan memberikan kekakuan rotasi. Pelat dimodelkan duduk di atas pondasi Pasternak. Penelitian ini menyatakan bahwa pada kecepatan kritis, amplitudo yang dihasilkan pada pelat mencapai tak hingga.

Meilani (2015) mempelajari tentang penggunaan MBM untuk memperoleh frekuensi alami pelat dengan perletakan semi rigid pada semua sisi pelat. Frekuensi alami pelat dan eigen vector diperoleh dengan analisis numerik menggunakan Mathematica 5.2 dan Microsoft Excel 2003. Pada penelitian ini akan dikaji mengenai respons dinamik pelat isotropik dengan perletakan semi rigid yang diselesaikan dengan MBM dan persamaan pelat seperti yang telah disebutkan sebelumnya. Beban yang diberikan pada pelat berupa beban transversal dinamik yang bergerak dengan kecepatan konstan.Kemudian akan dikaji bagaimana pengaruh kecepatan sistem terhadap respons dinamik pelat tersebut.

Kecepatan yang dianalisis dalam penelitian ini adalah saat kecepatan $10 \mathrm{~km} / \mathrm{jam}, 20 \mathrm{~km} / \mathrm{jam}, 30$ $\mathrm{km} / \mathrm{jam}$, dan $110 \mathrm{~km} / \mathrm{jam}$ (sebagai pembanding). Kemudian respons dinamik pelat akan ditinjau kembali dan dibandingkan berdasarkan kecepatan sistem. Juga akan ditinjau respons dinamik pelat saat mendekati kecepatan kritis sistem. Kondisi ini perlu untuk ditinjau karena respons pelat (lendutan pelat) akan mencapai maksimum saat sistem mendekati kecepatan kritis (Lu, 2006).

\section{Metode}

Penelitian ini dilakukan dengan metode analisis numerik dengan menggunakan bantuan program 
Mathematica 10.2 dan Microsoft Excel tanpa melakukan eksperimen atau percobaan untuk memperoleh data. Ada beberapa tahapan pada penelitian ini, yaitu (1) Tahap I berisi studi literature, tahap II berisi penyelesaian persamaan pelat dan persamaan auxiliary untuk memperoleh waktu getar alami system, tahap III berisi Input data geometri dan material pelat lantai, serta input beban dinamik pada program Mathematica, tahap IV berisi analisis defleksi dinamik, riwayat waktu, dan gaya dalam pada pelat dan tahap $\mathrm{V}$ berisi pembahasan hasil pengujian, kesimpulan, dan saran

\section{Penyelesaian persamaan transendental dan getaran paksa}

Untuk masalah auxiliary $I$, solusi fungsi posisi di arah x yang tak bersatuan dapat dinyatakan sebagai berikut:

$W_{m n}(\xi, \eta)=\sum_{m=1}^{m} \sum_{n=1}^{n} X_{m n}(\xi) \sin (\pi q \eta)$

Masalah yang ditinjau adalah perletakan semi rigid sehingga berlaku hubungan sebagai berikut di sisi $\xi=0$ dan di sisi $\xi=1$ (untuk persamaan tak bersatuan) :

$X_{m n}(\xi)=0$;

$\left(\frac{\partial^{2} W(\xi, \eta)}{\partial \xi^{2}}\right)+v \cdot s^{2}\left(\frac{\partial^{2} W(\xi, \eta)}{\partial \eta^{2}}\right)=-\overline{k_{1}} \cdot s\left(\frac{\partial W(\xi, \eta)}{\partial \xi}\right)$

dengan $\overline{k_{1}}=\left(\frac{k_{1} \cdot b}{D}\right)$, yaitu koefisien kekakuan rotasi non-dimensional arah $\xi$.

Kemudian dengan mensubstitusikan persamaan (11) ke persamaan (10) dan sesuai dengan syarat batas pada persamaan (12), maka diperoleh fungsi posisi arah $\mathrm{x}$ sebagai berikut:

$X(\xi)=\sum_{m=1}^{m} \sum_{n=1}^{n} \cos (p \pi \xi)+F_{1} \sin (p \pi \xi)-\cosh (\beta \pi \xi)+F_{2} \sinh (\beta \pi \xi)$

dengan:

$$
\begin{aligned}
& \beta=\sqrt{p^{2}+2 s^{2} q^{2}} \\
& F_{1}=-\frac{\beta \cos (p \pi)}{\beta \sin (p \pi)-p \sinh (\pi \beta)}+\frac{\beta \cosh (\pi \beta)}{\beta \sin (p \pi)-p \sinh (\pi \beta)} \\
& -\frac{p^{2} \pi \sinh (\pi \beta)}{s \bar{k}_{1}(\beta \sin (p \pi)-p \sinh (\pi \beta))}-\frac{\beta^{2} \pi \sinh (\pi \beta)}{s \bar{k}_{1}(\beta \sin (p \pi)-p \sinh (\pi \beta))} \\
& F_{2}=-\frac{p \cos (p \pi)}{\beta \sin (p \pi)-p \sinh (\pi \beta)}-\frac{p \cosh (\pi \beta)}{\beta \sin (p \pi)-p \sinh (\pi \beta)} \\
& +\frac{p^{2} \pi \sin (p \pi)}{s \bar{k}_{1}(\beta \sin (p \pi)-p \sinh (\pi \beta))}+\frac{\beta^{2} \pi \sin (p \pi)}{s \bar{k}_{1}(\beta \sin (p \pi)-p \sinh (\pi \beta))}
\end{aligned}
$$

Masalah auxiliary II yaitu memecahkan solusi fungsi posisi di arah y yang tak bersatuan dari yang dinyatakan sebagai berikut:

$$
W_{m n}(\xi, \eta)=\sum_{m=1}^{m} \sum_{n=1}^{n} \sin (\pi p \xi) Y_{m n}(\eta)
$$

Masalah yang ditinjau pada penelitian ini adalah perletakan semi rigid sehingga berlaku hubungan sebagai berikut di sisi $\eta=0$ dan $\eta=1$ (untuk persamaan tak bersatuan) :

$$
Y_{m n}(\eta)=0 ;\left(\frac{\partial^{2} W(\xi, \eta)}{\partial \eta^{2}}+\frac{v}{s^{2}} \frac{\partial^{2} W(\xi, \eta)}{\partial \xi^{2}}\right)=-\frac{\overline{k_{2}}}{s} \frac{\partial W(\xi, \eta)}{\partial \eta}
$$

dengan $\overline{k_{2}}=\left(\frac{k_{2} \cdot a}{D}\right)$, yaitu koefisien kekakuan rotasi non-dimensional arah $\eta$.

Kemudian dengan mensubstitusikan persamaan (17) ke persamaan (10) dan sesuai dengan syarat batas pada persamaan (18), maka diperoleh fungsi posisi arah y sebagai berikut:

$Y_{m n}(\eta)=\sum_{m=1}^{m} \sum_{n=1}^{n} \cos (q \pi \eta)+F_{3} \sin (q \pi \eta)-\cosh (\theta \pi \eta)+F_{4} \sinh (\theta \pi \eta)$

dengan:

$\theta=\frac{1}{s} \sqrt{2 p^{2}+s^{2} q^{2}}$

$F_{3}=-\frac{\bar{k}_{2} \theta \cos (\pi q)-\bar{k}_{2} \theta \cosh (\pi \theta)+s \pi\left(q^{2}+\theta^{2}\right) \sinh (\pi \theta)}{\bar{k}_{2}(\theta \sin (\pi q)-q \sinh (\pi \theta)}$

$F_{4}=-\frac{\bar{k}_{2} q \cos (\pi q)-\bar{k}_{2} q \cosh (\pi \theta)+s \pi\left(q^{2}+\theta^{2}\right) \sin (\pi q)}{\bar{k}_{2}(\theta \sin (\pi q)-q \sinh (\pi \theta)}$

Penyelesaian nilai $\mathrm{p}$ dan $\mathrm{q}$ yang merupakan akarakar persamaan transendental dapat diselesaikan dari persamaan berikut:

$$
\begin{aligned}
& -2 s^{2} \bar{k}_{1}^{2} p \beta+2 s^{2} \bar{k}_{1}^{2} p \beta \cdot \cos (p \pi) \cosh (\pi \beta)+ \\
& \left(s^{2} \bar{k}_{1}^{2}\left(p^{2}-\beta^{2}\right)+\pi^{2}\left(p^{2}+\beta^{2}\right)^{2}\right) \cdot \sin (p \pi) \sinh (\pi \beta)=0 \\
& -2 \bar{k}_{2}^{2} q \theta+2 \bar{k}_{2}^{2} q \theta \cdot \cos (q \pi) \cosh (\pi \theta)+ \\
& \left(\bar{k}_{2}^{2}\left(q^{2}-\theta^{2}\right)+s^{2} \pi^{2}\left(q^{2}+\theta^{2}\right)^{2}\right) \cdot \sin (q \pi) \sinh (\pi \theta)=0
\end{aligned}
$$

Setelah nilai $\mathrm{p}$ dan q telah diperoleh, maka frekuensi alami sistem non-dimensional juga dapat diperoleh dengan persamaan sebagai berikut:

$$
\varpi^{2}=\left\lfloor(p \pi)^{4}+2 s^{2}\left(p q \pi^{2}\right)^{2}+s^{4}(q \pi)^{4}\right\rfloor
$$

Kemudian untuk perhitungan getaran paksa, frekuensi alami non-dimensional tersebut diubah kembali menjadi frekuensi alami dimensional dengan hubungan sebagai berikut:

$$
\varpi=\omega \sqrt{\frac{a^{4} \rho h}{D}}
$$

Dimana $\varpi$ merupakan frekuensi alami nondimensional dan $\omega$ merupakan frekuensi alami dimensional. Setelah penyelesaian persamaan transendental, maka tahapan berikutnya yang 
dilakukan adalah penyelesaian persamaan beban dinamik dan getaran paksa.

Beban kendaraan yang bergerak pada permukaan pelat beton merupakan beban roda bus pariwisata $\mathrm{P}_{\mathrm{z}}(\mathrm{x}, \mathrm{y}, \mathrm{t})$ dan bekerja membebani permukaan pelat tersebut. Beban dinamik ini dapat dirumuskan sebagai berikut :

$$
P_{Z}(x, y, t)=P(t) \cdot \delta[x-x(t)] \cdot \delta[y-y(t)]
$$

Besarnya beban $\mathrm{P}(\mathrm{t})$ yang merupakan fungsi waktu dapat dinyatakan sebagai :

$$
\mathrm{P}(\mathrm{t})=\mathrm{P}_{0}+\mathrm{P}(\mathrm{t})=\mathrm{P}_{0}(1+\alpha \cdot \operatorname{Cos}[\omega \mathrm{t}])
$$

Dimana $\mathrm{P}_{0}$ merupakan beban tengah rata-rata dan merupakan beban ekuivalen roda kendaraan (equivalent single axle load, ESAL). $\alpha$ merupakan koefisien beban, merupakan fungsi dari suspensi roda kendaraan dan kekasaran permukaan jalan. $\Omega$ merupakan frekuensi beban. (t) merupakan fungsi gerak beban di arah $\mathrm{x}$ dengan kecepatan $\mathrm{v}, \mathrm{x}(\mathrm{t})$ merupakan fungsi gerak beban di arah $\mathrm{x}, \mathrm{y}(\mathrm{t})$ merupakan fungsi gerak beban di arah y, $\delta[$. merupakan fungsi Dirac-delta

Beberapa asumsi beban yang digunakan pada penelitian ini antara lain beban dinamik dianggap selalu bekerja dan menempel pada bidang tengah pelat sebagai beban resultan terpusat $\mathrm{P}_{0}$ (single point load). Besarnya beban terpusat $\mathrm{P}_{0}$ yang digunakan sebagai beban tengah rata-rata adalah resultan beban sumbu standar roda ganda atau roda kendaraan sumbu tunggal (equivalent single axle load, ESAL) yang besarnya adalah $100 \mathrm{kN}$. Arah gerak beban adalah searah dengan sumbu $\mathrm{x}$. Besarnya kecepatan kendaraan diambil sebesar 10 $\mathrm{km} / \mathrm{jam}$ sampai $30 \mathrm{~km} / \mathrm{jam}$ (untuk kecepatan kendaraan di daerah parkiran), $110 \mathrm{~km} / \mathrm{jam}$ (sebagai pembanding saat kondisi kritis pelat) dengan nilai frekuensi beban sebesar $80 \mathrm{rad} / \mathrm{s}$.

Fungsi beban dinamik tersebut dapat diselesaikan dengan integral Duhamel dan penyelesaiannya adalah sebagai berikut:

$\bar{T}_{p q}(t)+2 . \xi . \omega_{p q} \dot{T}_{p q}(t)+\omega_{p q}^{2} T_{p q}(t)=\frac{1}{\rho \cdot h \cdot Q_{p q}} \int_{x=0}^{a} \int_{y=0}^{b} X_{p q}(x) \cdot Y_{p q}(y) \cdot P_{z}(x, y, t) d x d y$

dengan $\mathrm{Q}_{\mathrm{pq}}$ adalah faktor normalisasi eigen vector sebagai berikut:

$Q_{p q}=\int_{x=0}^{a} \int_{y=0}^{b}\left(X_{p q}{ }^{2}(x) \cdot Y_{p q}{ }^{2}(y)\right) d x d y$

Penyelesaian dari integral Duhamel tersebut akan menghasilkan nilai lendutan pada pelat. Kemudian melalui nilai turunan kedua fungsi lendutan, akan diperoleh gaya dalam berupa momen lentur pada pelat. Sedangkan untuk gaya geser pada pelat diperoleh dari turunan ketiga dari fungsi lendutan pelat.

\section{Hasil dan Pembahasan}

Pelat beton yang dianalisis diasumsikan merupakan pelat yang dibebani oleh kendaraan jenis bus pariwisata. Beberapa parameter yang digunakan dalam analisis ini antara lain pelat beton bersifat elastis, homogen, dan isotropik serta dianalisis dengan menggunakan nilai kekakuan rotasi pada perletakan $(\bar{k})$ sebesar 0,5 (kondisi semi rigid) dan rasio redaman sebesar $5 \%$. .

Beban transversal pada pelat dimodelkan sebagai beban harmonis yang bergerak dengan kecepatan konstan di arah sumbu x (y bersifat konstan). Kecepatan yang dianalisis adalah sebesar 10 $\mathrm{km} / \mathrm{jam}$ sampai $30 \mathrm{~km} / \mathrm{jam}$ (untuk kecepatan kendaraan di daerah parkiran), $110 \mathrm{~km} / \mathrm{jam}$ (sebagai pembanding saat kondisi kritis pelat). Analisis dilakukan pada pelat tipis isotropik sesuai dengan teori Bernoulli dan hukum Hooke. Analisis dilakukan sesuai dengan teori lendutan kecil (small deflection theory) yaitu defleksi maksimum pelat tidak melebihi 1/10 dari ketebalan pelat.

Dimensi pelat beton yang digunakan untuk analisis adalah berdasarkan asumsi ukuran pelat yang digunakan pada pelat parkir untuk bus pariwisata. Karakteristik pemodelan pelat dapat dilihat pada Tabel 1.

Tabel 1. Data pelat

\begin{tabular}{clcc}
\hline Notasi & \multicolumn{1}{c}{ Keterangan } & Nilai & Satuan \\
\hline a & Panjang pelat & 5 & $\mathrm{~m}$ \\
$\mathrm{~s}$ & $\begin{array}{l}\text { Perbandingan Panjang } \\
\text { dan lebar pelat }\end{array}$ & 1 & \\
$\mathrm{~h}$ & Tebal pelat & 0,15 & $\mathrm{~m}$ \\
$\rho$ & Massa jenis beton & 2400 & $\mathrm{~kg} / \mathrm{m}^{3}$ \\
$\mathrm{E}_{\mathrm{x}}$ & Modulus elastisitas arah $2,35 \times 10^{10}$ & $\mathrm{~N} / \mathrm{m}^{2}$ \\
& $\mathrm{x}$ & \\
$\mathrm{E}_{\mathrm{y}}$ & Modulus elastisitas arah $2,35 \times 10^{10}$ & $\mathrm{~N} / \mathrm{m}^{2}$ \\
& y & \\
$v_{\mathrm{x}}$ & Poisson ratio arah x \\
$v_{\mathrm{y}}$ & Poisson ratio arah y & 0,3 & - \\
$\mathrm{D}_{\mathrm{x}}$ & Kekakuan lentur arah x & $7,26 \times 10^{6}$ & $\mathrm{Nm}$ \\
$\mathrm{D}_{\mathrm{y}}$ & Kekakuan lentur arah y & $7,26 \times 10^{6}$ & $\mathrm{Nm}$ \\
\hline
\end{tabular}

Berdasarkan data pelat tersebut, akan dilakukan analisis untuk memperoleh kecepatan kritis pelat dan gaya-gaya dalam pelat Kecepatan kritis merupakan kecepatan gerak beban yang diperlukan untuk menyebabkan respons maksimum pada pelat. Grafik kecepatan kritis sistem dapat dilihat pada Gambar 2. Berdasarkan grafik tersebut, maka kecepatan kritis sistem adalah sebesar 112 km/jam. 


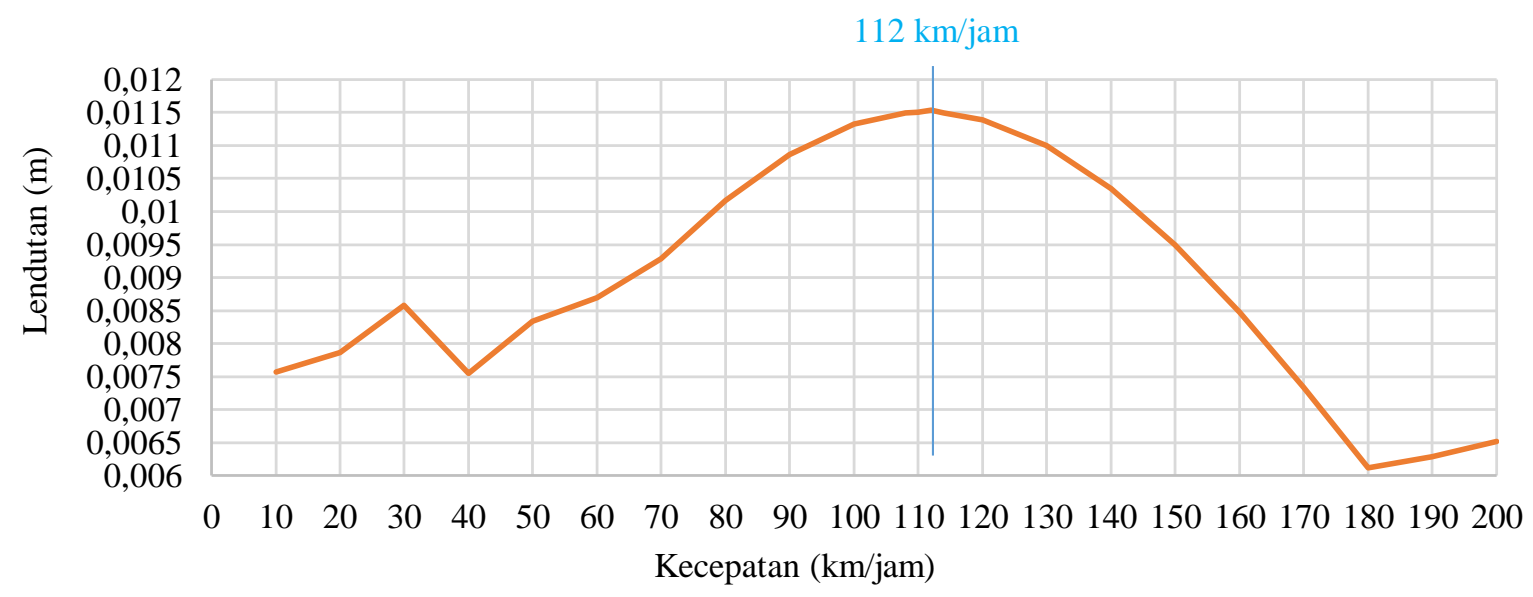

Gambar 2. Grafik kecepatan kritis

Perhitungan gaya-gaya dalam dilakukan pada posisi beban transversal saat menghasilkan defleksi maksimum untuk setiap kecepatan sistem. Momen pada pelat diperoleh dari turunan kedua fungsi lendutan sedangkan gaya geser pada pelat diperoleh dari turunan ketiga fungsi lendutan. Gambar 3 sampai Gambar 6 menunjukkan grafik momen dan gaya geser pelat arah $\mathrm{x}$ dan y pada saat posisi beban transversal ada di tengah bentang, yaitu pada saat beban berada di $\mathrm{x}=2,5 \mathrm{~m}$.

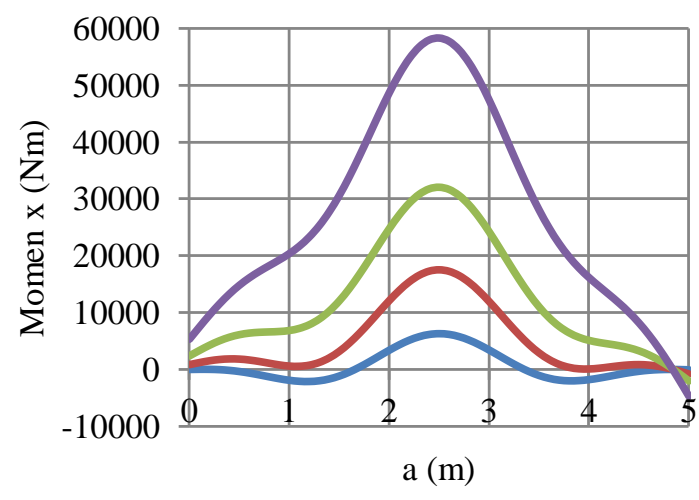

$\longrightarrow v=10-v=20-v=30-v=110$

Gambar 3. Grafik momen pelat arah X

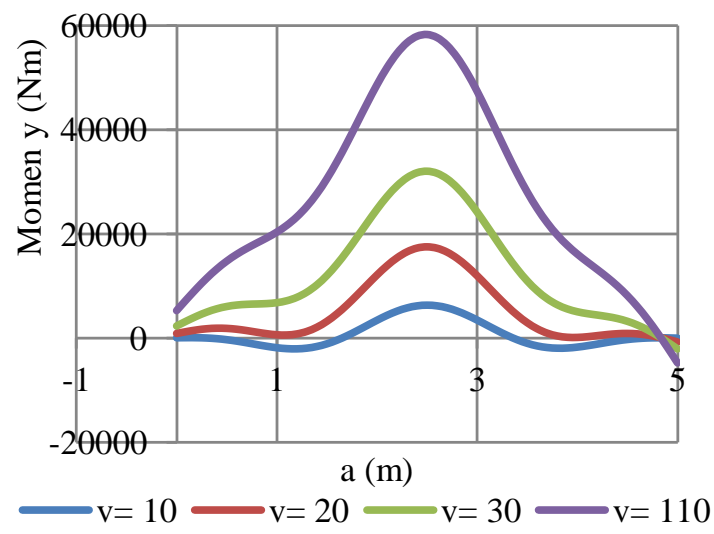

Gambar 4. Grafik momen pelat arah $Y$
Dari grafik tersebut terlihat bahwa setiap kecepatan sistem memiliki karakteristik dan sifat yang berbeda-beda sehingga respons gaya dalam maksimum yang dihasilkan tidak selalu berada di tengah bentang pelat pada sumbu yang dibebani beban transversal, dalam kasus ini adalah arah $\mathrm{x}$. Sedangkan untuk arah y yang bersifat konstan, momen dan defleksi maksimum tetap cenderung terjadi di pusat pelat.

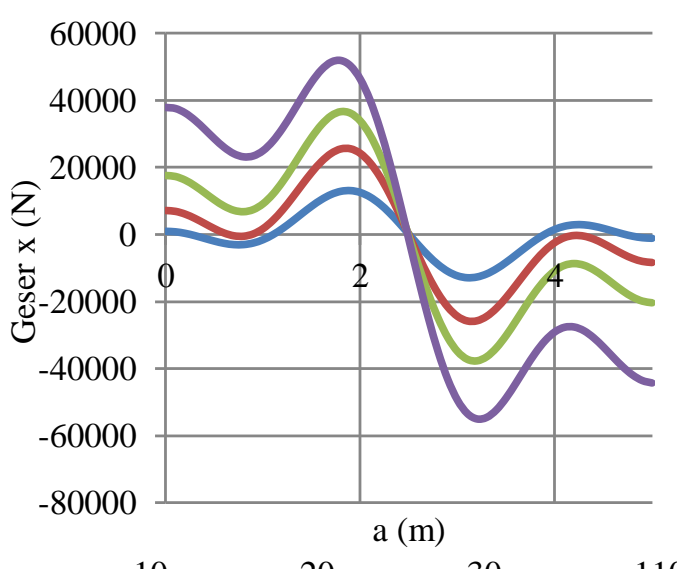

Gambar 5. Grafik gaya geser pelat arah X

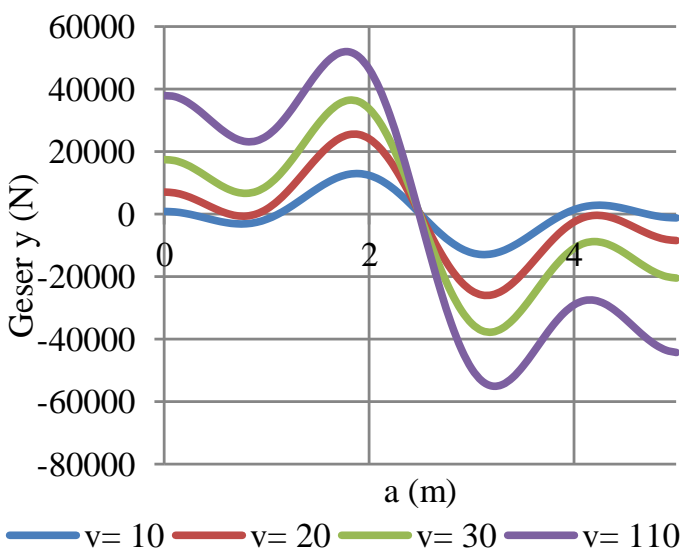

Gambar 6. . Grafik gaya geser pelat arah $Y$ 


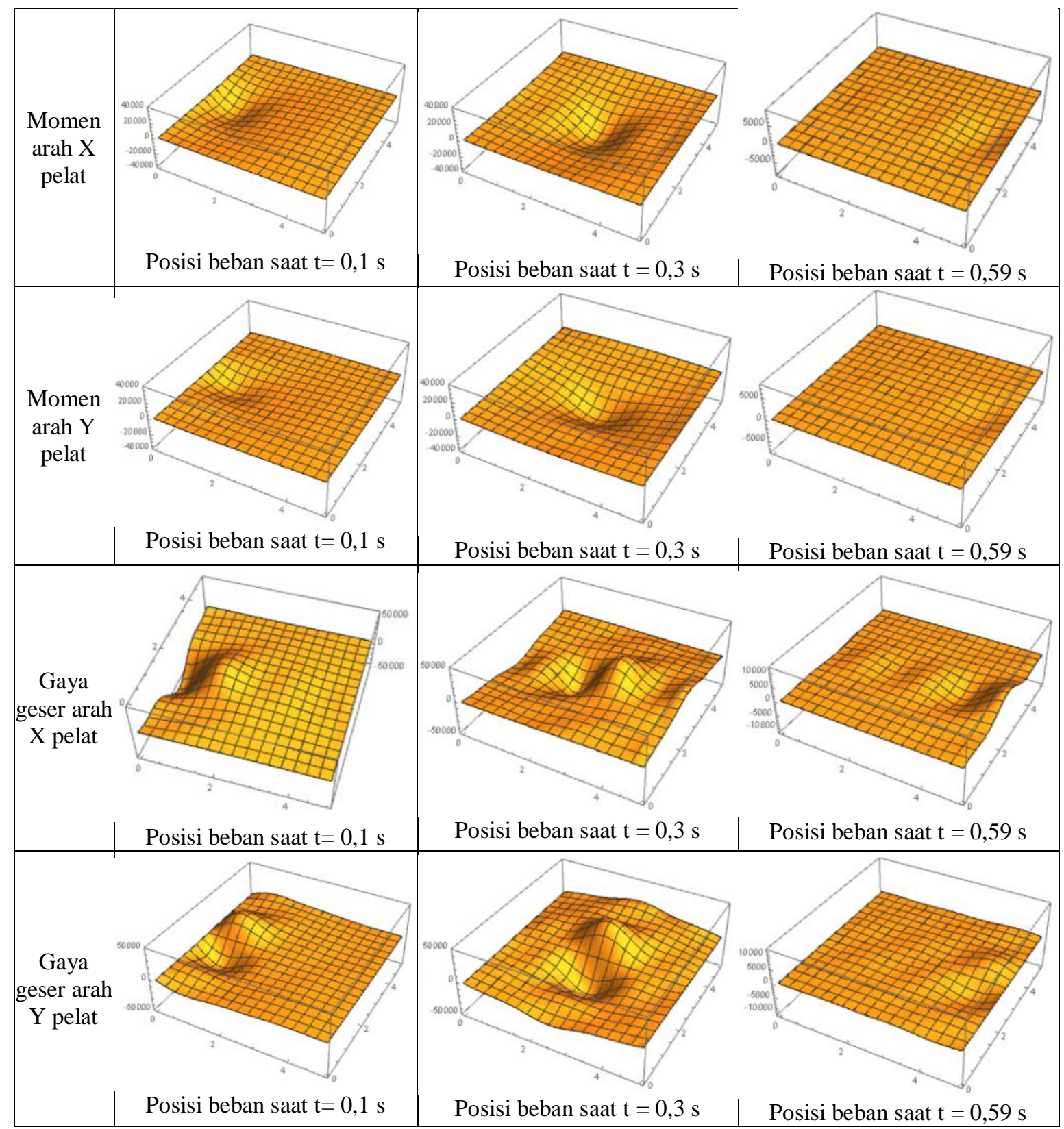

Gambar 7. Momen dan Gaya Geser Arah X dan Arah Y dalam 3D Saat Kecepatan Sistem 30 km/jam

Sesuai dengan grafik lendutan berdasarkan kecepatan (Gambar 2), maka gaya dalam sistem akan mendekati maksimum pada kecepatan 110 $\mathrm{km} / \mathrm{jam}$, yaitu pada saat kondisi mendekati kecepatan kritisnya. Pada pelat untuk parkir bis pariwisata, asumsi kecepatan yang terjadi pada sistem adalah sekitar $10 \mathrm{~km} / \mathrm{jam}$ sampai dengan 30 $\mathrm{km} / \mathrm{jam}$.

Analisis gaya dalam yang terjadi pada pelat yang ditunjukkan pada Gambar 3 sampai 6, membuktikan bahwa dengan kecepatan demikian masih jauh dari kondisi kritis sistem. Maka, properti pelat aman untuk digunakan. Berdasarkan grafik gaya dalam pelat pada Gambar 4 sampai 6 sebelumnya, maka pada Gambar 7 diperlihatkan model tiga dimensi gaya dalam tersebut. Model tiga dimensi ini diambil saat kecepatan sistem 30 $\mathrm{km} / \mathrm{jam}$.

\section{Kesimpulan}

Berdasarkan hasil analisis respons dinamik dengan variasi kecepatan sistem yang dibebani oleh beban transversal dengan kecepatan konstan, maka dapat disimpulkan bahwa kecepatan kritis sistem yang dianalisis, yaitu besarnya kecepatan sistem yang menghasilkan defleksi maksimum adalah pada kecepatan $112 \mathrm{~km} / \mathrm{jam}$. Setiap kecepatan sistem memiliki karakteristik yang berbeda-beda sehingga respons gaya dalam maksimum tidak selalu terjadi di pusat pelat untuk sumbu yang dilewati oleh 
sistem tersebut. Defleksi dan gaya dalam yang dihasilkan akan maksimum bila mendekati kecepatan kritis sistem. Maka, dengan menghitung kecepatan kritis pelat, kita dapat mengetahui apakah desain pelat yang digunakan aman atau tidak. Hal ini terbukti dari respons gaya dalam yang jauh lebih kecil disaat kecepatan sistem jauh di bawah kecepatan kritis sistem.

\section{Daftar Pustaka}

Alisjahbana, S. W., \& Wangsadinata, W. (2006). Dynamic Response of Rectangular Orthotropic Plate Supported by Pasternak Foundation Subjected to Dynamic Load. Paper presented at First International Structural Specialty Conference, Calgary, Alberta, Canada.

Alisjahbana, S. W., \& Wangsadinata, W. (2008). Dynamic Response of Damped Orthotropic Plate on Pasternak Foundation to Dynamic Moving Loads. Paper presented at Innovations in Structural Engineering and Construction, Taylor \& Francis Group, London. ISBN 978-0-415-45755-2.

Alisjahbana, S. W., \& Wangsadinata, W. (2012). Dynamic Analysis of Rigid Roadway Pavement Under Moving Traffic Loads with Variable Velocity. Interaction and Multiscale Mechanics, 5(2), 105-114.

Are, E. B., Idowu, A. S., Gbadeyan, J. A. (2013). Vibration of Damped Simply Supported Orthotropic Rectangular Plates Resing on Elastic Winkler Foundation, Subjected to Moving Loads. Applied Science Research 2013, 4(5), 387-393.

Beskou, N. D. \& Theodorakopoulos, D. D. (2011). Dynamic Effects of Moving Loads on Road Pavements. Soil Dynamics and Earthquake Engineering, 31(4), 547-567.

Chopra, A. K. (2012). Dynamics of structures theory and applications to earthquake engineering $\left(4^{\text {th }} e d.\right)$. Inc., Singapore: Prentice Hall International.

Elishakoff, I. B. (1974). Vibration Analysis of Clamped Square Orthotropic Plate. AIAA Journal, 12(7), July 1974.
Gbadeyan, J. A., et al (2008). The Effect of Viscous Damping on Isotropic Rectangular Plates Resting on Pasternak Foundations, Subjected to Moving Loads. International Journal of Mathematics and Statistical Studies, 1(2), 12-19 published by European Journal of Research, Training, and Developments, UK.

Gibigaye, M., Yabi, C. P., \& Alloba, I. E. (2016). Dynamic Response of a Rigid Pavement Plate Based on an Inertial Soil. Journal of International Scholarly Research Notices, doi: [10.1155/2016/4975345].

Idowu, A. S., et al (2013). Dynamics Effects of Viscous Damping on Isotropic Rectangular Plates Resting on Pasternak Foundation, Subjected to Moving Loads. International Journal of Mathematics and Statistical Studies, 1(2),12-19.

King, W. W., \& Lin, C. C. (1973). Applications of Bolotin's Method to Vibrations of Plates. AIAA Journal, 12(3), September 1973.

Lu, S. (2006). Analytical Dynamic Displacement Response of Rigid Pavements to Moving Concentrated and Line Loads. International Journal of Solids and Structures, 43(14-15), 43704383.

Meilani. (2015). Obtaining The Natural Frequency of Stiffened Plate with Modified Bolotin Method. International Journal of Applied Engineering Research, 9(23), 21501-21512.

Paz, M. (1985). Structural dynamics: theory and computation ( $2^{\text {nd }}$ ed.). New York: Chapman \& Hall.

Pevzner, P., Weller, T., \& Berkovits, A. (2000). Further Modification of Bolotin Method in Vibration Analysis of Rectangular Plate. AIAA Journal, 38(9).

Szilard, R. (1974). Theory and analysis of plates: classical and numerical methods., Inc., New Jersey: Prentice Hall.

Timoshenko, S. P. dan Goodier, J. N. (1951). Theory of elasticity. Engineering Societies Library, New York: McGraw-Hill Book Company. 